\title{
Association of Hyperglycemia with In-Hospital Mortality in Septicemia
}

\author{
Muhammad Naeem Afzal, ${ }^{1}$ Asim Khan, ${ }^{2}$ Syed Waqas Ali, ${ }^{3}$ Nisar Ahmad, ${ }^{4}$ Muhammad Sajid Sohail, ${ }^{5}$ \\ Waqar Ali, ${ }^{6}$ Irshad Hussain Qureshi ${ }^{7}$
}

\begin{abstract}
Objective: To document association of hyperglycemia with mortality in septicemic patients.

Methods: After approval from departmental review committee, this retrospective comparative study was conducted from the chart review of 197 medical files of patients with primary diagnosis of bacterial sepsis admitted in a medical unit of department of Internal Medicine, King Edward Medical University Lahore from October 2012 to Septfember 2013. Sepsis was defined as by international sepsis definitions conference criteria 2001. "Diabetics" were evident from history; the term non-diabetic was used for the rest. Highest blood sugar value recorded during admission with Optium Xceed glucometer was used for analysis. Mean blood sugar of discharged and deceased patients
\end{abstract}

\footnotetext{
${ }^{1}$ Assistant Professor of Medicine, KEMU / Mayo Hospital, Lahore

${ }^{2}$ Neurospinal Hospital, Jumairah 2. Dubai, UAE. 71444. (Exresident, Internal Medicine, Mayo Hospital, Lahore - Pakistan).

${ }^{3}$ Resident, East Medical Ward, Mayo Hospital, Lahore

${ }^{4}$ Resident, Department of Cardiology, Mayo Hospital, Lahore

${ }^{5}$ Resident, East Medical Ward, Mayo Hospital, Lahore

${ }^{6}$ Resident, East Medical Ward, Mayo Hospital, Lahore

${ }^{7}$ Professor and Chairman Department of Medicine, KEMU / Mayo Hospital, Lahore
}

Date of Submission 22-02-2016

Date of Revision Received 10-05-2016

Date of Acceptance for Publication 09-06-2016

Conflict of Interest: None

Funding Source: None

\section{Contribution}

All Authors have contributed in Study Design, Data Collection, Data Analysis, Data Interpretation, Manuscript Writing and Approval. were compared (t-test), mortality of diabetic and nondiabetic patients was compared by frequency of hyperglycemia ( $\geq 200 \mathrm{mg} / \mathrm{dl}$ ) by chi-square test. SSPS version 20 was used. A p-value $<0.05$ was considered significant.

Results: Mean age of patients was 59.8 years, 92 $(46.7 \%)$ males, and $105(53.3 \%)$ were females. Mean blood sugar was high in known diabetics $(314 \pm 129$ $\mathrm{mg} / \mathrm{dl})$, and non-diabetics $(210 \pm 109 \mathrm{mg} / \mathrm{dl})$. Higher mean blood sugar was significantly associated with mortality in females $(p=0.032)$; trend towards significance was found in non-diabetic females $(p=0.065)$. Association of mortality in relation to hyperglycemia (Blood sugar $\geq 200 \mathrm{mg} / \mathrm{dl}$ ), was found significant in whole study group $(\mathrm{p}=0.038)$; sub-analysis revealed prominent association in non-diabetics $(\mathrm{p}=0.027)$, and females $(\mathrm{p}=0.04)$.

Conclusion: Despite certain limitations of this study, hyperglycemia (blood sugar $\geq 200 \mathrm{mg} / \mathrm{dl}$ ) may be a bad prognostic marker in septicemic non-diabetic female population; they need special attention for earlier and aggressive treatment.

Keywords: Mean blood glucose, sepsis, hyperglycemia, diabetics, non-diabetics.

\section{Introduction}

Stress hyperglycemia is frequent in critically ill patients and seems to be a marker of disease severity. Both admission glucose as well as mean glucose level during the hospital stay is strongly associated with patient outcomes. In-hospital hyperglycemia has been associated with significant increase in mortality in most of diseases. ${ }^{1}$ Different bodies in care of diabetic patients have issued guidelines on management of in- 
patient hyperglycemia in critical care $^{2}$ as well as noncritical care settings. ${ }^{3}$ It is established that adequate management of hyperglycemia improves the outcome in terms of mortality and length of hospital stay in acute coronary syndrome ${ }^{4}$ and stroke. ${ }^{5}$ Epidemiological data are appearing from Pakistan in cardiac and stroke patients, ${ }^{6,7}$ yet data in sepsis is lacking.

International literature on association of diabetes and outcome in sepsis also shows conflicting evidences. In some studies, presence of diabetes shows harmful effect on septicemia outcome, ${ }^{8-10}$ while some show no effect. ${ }^{11,12}$ Evidence also dichotomizes effect of hyperglycemia on diabetics and non-diabetics, depicting an unfavorable effect of hyperglycemia in nondiabetics. ${ }^{13}$ As there is no data from Pakistan on association of diabetes and sepsis, we planned this study to find out association of hyperglycemia in diabetic and non-diabetic septicemic patients in our population.

\section{Patients and Methods}

After approval from departmental review committee, this retrospective comparative study was conducted from the chart review for the patients admitted in a medical unit of department of Internal Medicine, King Edward Medical University Lahore from October 2012 to September 2013. A total of 197 medical files of patients with primary diagnosis of bacterial sepsis (identified by careful history and examination finding recorded in chart) were identified and enrolled in the study. Sepsis was defined as per international sepsis definitions conference criteria 2001, as presence of obvious source of infection plus presence of at least two of four clinical criteria (temperature $>101^{\circ} \mathrm{F}$ or $<97^{\circ} \mathrm{F}$, heart rate $>90$ beats/min, respiratory rate $>20 / \mathrm{min}$, altered conscious level not attributable to neurological or metabolic cause, White cell count $>12$ $\times 10^{9}$ or $\left.<4 \times 10^{9} / \mathrm{cmm}\right) .{ }^{14}$ Those with unidentifiable source of sepsis or alternative cause of any four clinical indicators of sepsis were excluded from analysis. "Diabetics" were evident from history or drugs they were taking. Others, who were not known to be diabetic, were taken as "non-diabetic" for the purpose of analysis. To measure the blood glucose level, "Optium Xceed" glucometer was used to check blood glucose levels in ward and values were counter - checked with lab (weekly as per ward routine). Highest blood sugar level recorded on any day during admission was kept for analysis. Mean blood sugar level of expired versus discharged patients was compared in diabetics and non-diabetics using independent t-test. Mortality outcome was compared with hyperglycemia (Blood sugar $\geq 200 \mathrm{mg} / \mathrm{dl}$ ) using Chi-square test. Sub-analyses per gender were also done on same lines. SPSS software version 20 was used for statistical analyses. A p-value $<0.05$ was considered significant.

\section{Results}

A total of 197 cases of septicemia were identified from review of charts. Among these, 92 (46.7\%) were male, and $105(53.3 \%)$ were females. Mean age of our patients was 59.8years. Mean blood sugar was significantly higher in known diabetics as well as in nondiabetics (Table 1).

Comparison of mean blood sugar showed that higher blood sugar level during admission $(\geq 200$ $\mathrm{mg} / \mathrm{dl}$ ) was statistically significantly associated with mortality in females overall $(\mathrm{p}=0.032)$, and a trend towards significance was found in non-diabetic females $(p=0.065)$ but it was insignificant in diabetic females $(p=0.57)$; it was also insignificant in males whether diabetic or non-diabetic (Table 2).

When association of mortality was determined in relation to hyperglycemia (Blood sugar $\geq 200 \mathrm{mg} / \mathrm{dl}$ ), it was found statistically significant in whole study group; sub-analysis here also revealed more prominent association in non-diabetic subgroup and females. (Table 3).

\section{Discussion}

Acute stress induced hyperglycemia is associated with increased production of inflammatory cytokines in septic patients that leads to worse outcomes. ${ }^{15}$ Our study also shows statistically significant association of mortality in septicemic patients having blood sugar level $\geq 200 \mathrm{mg} / \mathrm{dl}$. Another study already reported in international literature regarding association of hyperglycemia with mortality in septicemic patients show more deleterious association of hyperglycemia in nondiabetic critically ill patients than diabetic cohort. ${ }^{13}$ Results of our study are in accordance with available literature that shows that hyperglycemia is more dangerous in non-diabetics female population. Interestingly, the same association with non-diabetics was also reported in a Japanese cohort of acute myocardial infarction patients. ${ }^{16}$ A recently published meta-analysis also concluded that patients with new-onset hyper- 
Table 1: Baseline characteristics of study population.

\begin{tabular}{|l|c|c|c|c|c|}
\hline & $\begin{array}{c}\text { Age } \\
\text { Mean } \pm \text { SD) }\end{array}$ & $\begin{array}{c}\text { Highest Blood } \\
\text { Sugar mg/dl } \\
(\text { Mean } \pm \text { SD) }\end{array}$ & $\begin{array}{c}\text { Blood Sugar } \\
\geq 200 \mathrm{mg} / \mathrm{dl}\end{array}$ & $\begin{array}{c}\text { Blood Sugar } \\
\geq 350 \mathrm{mg} / \mathrm{dl}\end{array}$ & $\begin{array}{c}\text { Expired } \\
\text { All patients }(\mathrm{n}=197)\end{array}$ \\
\hline Males $(\mathrm{n}=92)$ & $61.6 \pm 20.4$ & $251 \pm 132$ & $56(60.9 \%)$ & $19(20.7 \%)$ & $56(60.9 \%)$ \\
\hline Females $(\mathrm{n}=105)$ & $58.2 \pm 18.4$ & $250 \pm 124$ & $62(59 \%)$ & $21(20 \%)$ & $49(46.7 \%)$ \\
\hline Known Diabetic $(\mathrm{n}=77)$ & $61.7 \pm 13.4$ & $314 \pm 129$ & $60(77.9 \%)$ & $29(37.7 \%)$ & $43(55.8 \%)$ \\
\hline Not known diabetic $(\mathrm{n}=120)$ & $58.6 \pm 22.3$ & $210 \pm 109$ & $58(48.3 \%)$ & $11(9.2 \%)$ & $62(51.7 \%)$ \\
\hline
\end{tabular}

Table 2: Comparison of mean blood sugar levels $(\mathrm{mg} / \mathrm{dl})$ in discharged versus expired patients (t-test).

\begin{tabular}{|c|c|c|c|c|c|c|c|c|c|}
\hline & \multicolumn{3}{|c|}{ All Patients } & \multicolumn{3}{|c|}{ Males } & \multicolumn{3}{|c|}{ Females } \\
\hline & $\begin{array}{c}\text { All } \\
\mathbf{N}=197\end{array}$ & $\begin{array}{c}\text { Known } \\
\text { Diabetic } \\
\mathbf{N}=77\end{array}$ & $\begin{array}{c}\text { Not } \\
\text { Known } \\
\text { Diabetic } \\
\text { N = 120 }\end{array}$ & $\begin{array}{c}\text { All } \\
\mathbf{N}=92\end{array}$ & $\begin{array}{c}\text { Known } \\
\text { Diabetic } \\
\mathbf{N}=\mathbf{2 8}\end{array}$ & $\begin{array}{c}\text { Not } \\
\text { Known } \\
\text { Diabetic } \\
\text { N = 64 }\end{array}$ & $\begin{array}{c}\text { All } \\
N=105\end{array}$ & $\begin{array}{c}\text { Known } \\
\text { Diabetic } \\
\mathbf{N}=49\end{array}$ & $\begin{array}{c}\text { Not } \\
\text { Known } \\
\text { Diabetic } \\
\mathrm{N}=56\end{array}$ \\
\hline Discharged & $\begin{array}{c}238.9 \pm \\
132.6 \\
(n=92)\end{array}$ & $\begin{array}{c}307.3 \pm \\
122.9 \\
(n=34)\end{array}$ & $\begin{array}{c}198.8 \pm \\
121.9 \\
(n=58)\end{array}$ & $\begin{array}{c}258.1 \pm \\
149.2 \\
(n=36)\end{array}$ & $\begin{array}{c}326.5 \pm \\
136.7 \\
(n=12)\end{array}$ & $\begin{array}{c}223.9 \pm \\
145.9 \\
(n=24)\end{array}$ & $\begin{array}{c}226.6 \pm \\
120.5 \\
(n=56)\end{array}$ & $\begin{array}{c}296.8 \pm \\
116.8 \\
(n=22)\end{array}$ & $\begin{array}{c}181.1 \pm \\
100.4 \\
(n=34)\end{array}$ \\
\hline Expired & $\begin{array}{c}261.6 \pm \\
122.9 \\
(n=105)\end{array}$ & $\begin{array}{c}319.4 \pm \\
134.7 \\
(n=43)\end{array}$ & $\begin{array}{c}221.5 \pm \\
96.3 \\
(n=62)\end{array}$ & $\begin{array}{c}246.9 \pm \\
121.4 \\
(n=56)\end{array}$ & $\begin{array}{c}321.6 \pm \\
133.9 \\
(n=16)\end{array}$ & $\begin{array}{c}217.0 \pm \\
103.4 \\
(n=40)\end{array}$ & $\begin{array}{c}278.4 \pm \\
123.8 \\
(n=49)\end{array}$ & $\begin{array}{c}318.1 \pm \\
137.8 \\
(n=27)\end{array}$ & $\begin{array}{c}229.7 \pm \\
83.8 \\
(n=22)\end{array}$ \\
\hline p-value & 0.215 & 0.68 & 0.26 & 0.69 & 0.92 & 0.82 & 0.032 & 0.57 & 0.065 \\
\hline
\end{tabular}

Table 3: Association of death with hyperglycemia ( $\geq 200 \mathrm{mg} / \mathrm{dl})$ (Chi-Square test).

\begin{tabular}{|c|c|c|c|c|c|c|c|c|c|}
\hline & \multicolumn{3}{|c|}{ All Patients } & \multicolumn{3}{|c|}{ Males } & \multicolumn{3}{|c|}{ Females } \\
\hline & $\begin{array}{c}\text { All } \\
N=197\end{array}$ & $\begin{array}{c}\text { Known } \\
\text { Diabetic } \\
\mathbf{N}=77\end{array}$ & $\begin{array}{c}\text { Not } \\
\text { Known } \\
\text { Diabetic } \\
\text { N = 120 }\end{array}$ & $\begin{array}{c}\text { All } \\
\mathbf{N}=92\end{array}$ & $\begin{array}{c}\text { Known } \\
\text { Diabetic } \\
\mathrm{N}=\mathbf{2 8}\end{array}$ & $\begin{array}{c}\text { Not } \\
\text { Known } \\
\text { Diabetic } \\
\text { N = } 64\end{array}$ & $\begin{array}{c}\text { All } \\
N=105\end{array}$ & $\begin{array}{c}\text { Known } \\
\text { Diabetic } \\
\mathrm{N}=49\end{array}$ & $\begin{array}{c}\text { Not } \\
\text { Known } \\
\text { Diabetic } \\
\mathrm{N}=\mathbf{5 6}\end{array}$ \\
\hline $\begin{array}{l}\text { BSL } \\
<200 \mathrm{mg} / \mathrm{dl}\end{array}$ & $\begin{array}{l}35 / 79 \\
(44 \%)\end{array}$ & $\begin{array}{c}9 / 17 \\
(53 \%)\end{array}$ & $\begin{array}{l}26 / 62 \\
(42 \%)\end{array}$ & $\begin{array}{l}20 / 36 \\
(56 \%)\end{array}$ & $\begin{array}{c}3 / 5 \\
(60 \%)\end{array}$ & $\begin{array}{l}17 / 31 \\
(55 \%)\end{array}$ & $\begin{array}{c}15 / 43 \\
(35 \%)\end{array}$ & $\begin{array}{c}6 / 12 \\
(50 \%)\end{array}$ & $\begin{array}{c}9 / 31 \\
(29 \%)\end{array}$ \\
\hline $\begin{array}{l}\mathrm{BSL} \geq 200 \\
\mathrm{mg} / \mathrm{dl}\end{array}$ & $\begin{array}{l}70 / 118 \\
(59 \%)\end{array}$ & $\begin{array}{l}34 / 60 \\
(57 \%)\end{array}$ & $\begin{array}{l}36 / 58 \\
(62 \%)\end{array}$ & $\begin{array}{l}36 / 56 \\
(64 \%)\end{array}$ & $\begin{array}{l}13 / 23 \\
(56 \%)\end{array}$ & $\begin{array}{l}23 / 33 \\
(70 \%)\end{array}$ & $\begin{array}{l}34 / 62 \\
(55 \%)\end{array}$ & $\begin{array}{l}21 / 37 \\
(57 \%)\end{array}$ & $\begin{array}{l}13 / 25 \\
(52 \%)\end{array}$ \\
\hline p-value & 0.038 & 0.78 & 0.027 & 0.40 & 0.88 & 0.22 & 0.040 & 0.68 & 0.08 \\
\hline
\end{tabular}

Numbers in rows show (expired/total) patients in respective category. Chi square test is applied.

glycemia had 2.7 times higher odds of in-hospital mortality as compared to known diabetics having similar blood sugar levels. ${ }^{17}$ The reason of less pronounced adverse effect of hyperglycemia in diabetics is not very clear, though it is proposed that diabetics have lesser immune mediated organ dysfunction and lung 
injury that prevents deleterious outcomes in diabetics as compared to non-diabetics. ${ }^{18}$

We additionally report that in our Pakistani population, association of hyperglycemia with in-hospital mortality is statistically significant in non-diabetic female population while it is insignificant in male population. This discovery underpins resource allocation in our resource restricted health setup. It signifies close monitoring of non-diabetic hyperglycemic females in septicemia whose outcome may possibly be improved by adequate glycemic control. The reason why hyperglycemia is a bad prognostic marker in non-diabetic females but not in males is yet to be evaluated. Hormonal influences can be a plausible explanation in gender differences, but as mean age of our study population is around 60 years, and females in this age group are post-menopausal, so most probably this explanation is not justifiable and needs further exploration.

There are certain limitations of our study. A gross limitation of this study is that non-diabetics were labeled only on the basis of history. It is quite possible that they are actually undiagnosed diabetic and that can be clarified with $\mathrm{HbA}_{1} \mathrm{c}$ on admission or follow up OGTT after termination of acute illness. As it has not been a routine activity in ward, so we relied only on available record, but we realize that further studies should incurporate improvement in methodology. However, we want to highlight that in hospitals like ours where $\mathrm{HbA} 1 \mathrm{c}$ is not routinely done due to issues of cost or availability, and doctors rely on history or available medical record to determine the diabetic status and modify or prioritize treatment accordingly, the message should be clear that female septicemic patients who are not known diabetic by history but they are hyperglycemic during admission may be at high risk of mortality and they should be given due attention to appropriate treatment. Another limitation of our study was that severity of septicemia was not graded as per serum lactate levels or according to a valid scoring system like APACHIE scoring system. We suggest that larger prospective studies should be done and septicemic patients may be categorized according to severity of illness to see association of hyperglycemia with outcome in different subgroups of septicemic patients. We further suggest that benefit of glucose lowering must be evaluated especially in non-diabetic females suffering from septicemia.

\section{Conclusion}

In our population, hyperglycemia (blood sugar $\geq 200$ $\mathrm{mg} / \mathrm{dl}$ ) may be a bad prognostic marker in septicemic non-diabetic female population; they need special atention for earlier and aggressive treatment.

\section{References}

1. Marik PE, Bellomo R. Stress hyperglycemia: an essential survival response! Crit Care. 2013; 17: 305.

2. Moghissi ES, Korytkowski MT, DiNardo M, Ein Horn D, Hellman R, Hirsch IB, et al. American Association of Clinical Endocrinologists and American Diabetes Association consensus statement on inpatient glycemic control. Diabetes Care, 2009; 32: 1119-31.

3. Umpierrez GE, Hellman R, Korytkowski MT, Kosiborod M, Maynard GA, Montori VM, et al. Management of hyperglycemia in hospitalized patients in noncritical care setting: an Endocrine Society clinical practice Guideline. J Clin Endocrinol Metab. 2012; 97: 1638.

4. Ishihara M. Acute hyperglycemia in patients with acute myocardial infarction. Circ J. 2012; 76 (3): 563-71.

5. Li WA, Moore-Langston S, Chakraborty T, Rafols JA, Conti AC, Ding Y. Hyperglycemia in stroke and possible treatments. Nurol Res. 2013; 35 (3): 479-91.

6. Khan FI, Khan A. Frequency of newly diagnosed diabetics in patients with acute myocardial infarction. J Ayub Med Coll Abbottabad, 2014; 26 (3): 368-70.

7. Rajput R, Yousfani AH, Shaikh MA. Effect of stress hyperglycemia on mortality rate among ischemic stroke patients. Med Channel, 2011; 17 (2): 32-5.

8. Benfield T, Jensen JS, Nordestgaard BG. Influence of diabetes and hyperglycemia on infectious disease hospitalization and outcome. Diabetologia. 2007; 50: 549-54.

9. Thomson RW, Hundborg HH, Lervang HH, Johnsen SP, Schonheyder HC, Sorensen HT. Diabetes mellitus as a risk and prognostic factor for community acquired bacteremia due to enterobacteria: a 10 year, population based study among adults. Clin Infect Dis. 2005; 40: 628-31.

10. Kornum JB, Thomsen RW, Riis A, Lervang HH, Schonheyder HC, Sorensen HT. Type 2 diabetes and pneumonia outcome; a population based cohort study. Diabetes Care, 2007; 30: 2251-7.

11. Stegenga ME, Vincent JL, Vail GM. Diabetes does not alter mortality or hemostatic and inflammatory responses in patients with severe sepsis. Cri Care Med. 2009; 38: 539-45.

12. Esper AM, Moss M, Martin GS. The effect of diabetes mellitus on organ dysfunction with sepsis: an epidemiological study. Crit Care. 2009; 13 (1): R18. doi: 10.1186/cc7717.

13. Graham BB, Keniston A, Gajic O, Trillo Alvarez CA, 
Medvedez S, Douglas IS. Diabetes mellitus does not adversely affect outcomes from a critical illness. Crit Care Med. 2010; 38: 16-24.

14. Levy MM, Fink MP, Marshall JC, Abraham E, Angus D, Cook D, et al; SCCM / ESCIM / ACCP / ATS / SIS. 2001 SCCM / ESCIM / ACCP / ATS / SIS international sepsis definitions conference. Crit Care Med. 2003; 31 (4): 1250-6.

15. Leonidou L, Mouzaki A, Michalaki M, DeLastic AL, Kyriazopoulou V, Bassaris HP. Cytokine production and hospital mortality in patients with sepsis - induced stress hyperglycemia. J Infect. 2007; 55 (4): 340-6.

16. Fujino M, Ishihara M, Honda S, Kawakami S, Yamane
T, Nagai T. Impact of acute and chronic hyper-glycemia on in-hospital outcomes of patients with acute myocardial infarction. Am J Cardiol. 2014; 114 (12): 1789-93.

17. Tayek CJ, Tayek JA. Diabetes patients and non-diabetic patients intensive care unit and hospital mortality risk associated with sepsis. World J Diabetes. 2012; 3 (2): 29-34.

18. Gu WJ, Wan YD, Tie HT, Kan QC, Sun TW. Risk of acute lung injury/acute respiratory distress syndrome in critically ill adult patients with pre-existing diabetes: a meta-analysis. PLoS One. 2014; 9(2): e90426.

Doi: 10.1371/journal.pone.0090426. 